\title{
ANALISIS KETIDAKAMANAN STREET FOOD DI SEPANJANG JALAN SILIWANGI
}

\author{
ANALYSIS OF UNSECURITY STREET FOODS IN ROADSIDE \\ SILIWANGI STREET
}

\author{
Lilik Hidayanti dan Nur Lina \\ Fakultas Ilmu Kesehatan Universitas Siliwangi Tasikmalaya
}

\begin{abstract}
ABSTRAK
Makanan jalanan merupakan salah satu makanan umum bagi mahasiswa S1. Banyak kontaminasi yang bisa mengotori makanan jalanan, seperti biologis, fisik, dan kontaminan kimia. Banyak masalah kesehatan bisa disebabkan oleh makanan yang terkontaminasi. Tujuan penelitian ini adalah untuk mengidentifikasi kontaminasi kimia pada makanan jalanan yang dijual di depan Universitas Siliwangi, jalan Siliwangi. Penelitian ini menggunakan metode survei dengan 37 sampel makanan jalanan yang diambil dari 18 penjual makanan. Kontaminan kimia diindikasikan menggunakan alat deteksi pencemaran makanan. Faktor individu seperti pendidikan, usia, dan pendapatan dan juga siapa penghasil jalan juga diukur dalam penelitian ini. Analisis Univariat menggunakan tabel distribusi frekuensi, grafik, dan nilai perhitungan statistik. Hasil penelitian ini sebagian besar adalah pendidikan responden yaitu SLTP dan SLTA. Rata-rata responden berusia 35 tahun, dan penghasilan harian Rp 314.000,00. Sebagian besar makanan jalanan diproduksi oleh penjual sendiri. Deteksi zat kimia menunjukkan boraks dan Rhodamin B tidak terdeteksi. Tapi formalin ditemukan di dua makanan jalanan. Rekomendasinya adalah terus memantau dan melakukan ecducating penjual makanan jalanan tanpa menggunakan bahan kimia tambahan.

Kata Kunci : makanan jalanan, tambahan makanan, penjual makanan
\end{abstract}

ABSTRACT

Street foods is one of common food for undergraduate students. There are many contaminat wich can contamined street foods, such as biological, phisical, and chemical contaminant. Many health problem can be caused by contaminated food. The purpose of this reseach is to indentify chemical contaminat in street foods that is sold in front of Siliwangi University, Siliwangi street. This research is using survey method with 37 sample of street foods that are taken from 18 food's seller. Chemical contaminant was indetify using food contaminat detection kit. Individual factor such as education, age, and income and also who is the producer of streets were also measured in this study. Univariat analysis use the frequency distribution table, graph, and statistical calculation values. The result of this research are most of the responden's education are yunior high school and senior high school. Average of respondens are 35 years old, and daily income are Rp $314.000,00$. Most of the street foods is produced by the own seller. Chemical contaminat detection showed borax and Rhodamin B aren't detected. But formalin is found in two street foods. The recomendation are continue monitoring and ecducating food street's seller abaout the impact of using chemical food additives.

Key words : Street food, Food additives, Food's seller

\section{PENDAHULUAN}

Makanan jajanan yang dijual

di pinggiran jalan atau kaki lima

dalam bahasa inggris disebut street

food. Menurut FAO, street food

didefinisikan sebagai makanan dan minuman yang dipersiapkan dan/atau

dijual oleh pedagang kaki lima di

jalan dan di tempat-tempat

keramaian umum lain yang dapat

langsung dimakan atau dikonsumsi

tanpa pengolahan atau persiapan 
lebih lanjut (FAO, 2007). Street food merupakan makanan yang mudah dijumpai di kawasan yang memiliki banyak tempat kost seperti lingkungan sekitar kampus (Susana, dkk, 2010). Kesibukan mahasiswa menyebabkan mereka tidak mau direpotkan dengan urusan penyediaan makan sehingga meningkatkan budaya makan di luar rumah. Oleh karena itu, banyaknya mahasiswa yang tinggal di tempat kost mengakibatkan menjamurnya street food di sekitar kampus.

Mahasiswa merupakan salah satu konsumen street food karena makanan ini biasa mereka beli dan makan setiap hari, mudah dijumpai di sekitar kampus dan harganya yang relatif terjangkau oleh mahasiswa. Namun apabila, street food tidak disiapkan secara baik sangat berisiko mengganggu kesehatan konsumennya baik jangka pendek maupun jangka panjang. Pada kenyataannya masih banyak produsen makanan yang menggunakan bahan tambahan pangan (BTP) yang berbahaya bagi kesehatan. Efek dari penggunaan BTP yang dilarang tidak dapat langsung dirasakan, tetapi secara perlahan dan pasti dapat menyebabkan sakit.

Badan pengawasan obat dan makanan (BPOM) mengungkapkan bahwa beberapa BTP yang sering digunakan pada makanan adalah formalin, rhodamin B, methanil yellow dan boraks. Semua BTP yang disebutkan tersebut dilarang penggunaannya untuk makanan dan dapat menimbulkan bahaya bagi kesehatan. Penggunaan BTP yang melebihi batas akan membahayakan kesehatan masyarakat, dan berbahaya bagi pertumbuhan generasi yang akan datang. Pada penelitian ini peneliti akan melakukan identifikasi semua BTP yang ada dalam makanan jajanan yang dijual di pinggir jalan (Street Food) dengan sebagian besar segmen konsumennya adalah mahasiswa. Segmen konsumen mahasiswa seharusnya membuat produsen lebih berhati-hati dalam menggunakan BTP karena mahasiswa memiliki pengetahuan dan pendidikan yang tinggi. Penelitian akan dilaksanakan di sepanjang jalan Siliwangi yang merupakan daerah kompleks kampus. Di sekitar jalan Siliwangi terdapat kampus Unsil, Unper, 
Poltekes, maupun Stikes BTH dengan jumlah pedagang makanan (street food) yang cukup banyak serta belum diketahui BTP digunakannya sesuai peraturan atau tidak

\section{METODE}

Penelitian ini merupakan penelitian survei yang bertujuan untuk menggambarkan penggunaan BTP yang dilarang (Formalin, Rhodamin B, dan Boraks) pada street food. Populasi dalam penelitian ini adalah street food yang dijual di Jalan Siliwangi depan Kampus Universitas Siliwangi. Populasi berjumlah 37 jenis street food yang dijual oleh 18 orang pedagang sebagai responden. Populasi dalam penelitian ini semuanya dijadikan sampel. Tahapan kegiatan penelitian meliputi ijin kepada pedagang, pengambilan sampel, memberi label pada sampel, menyimpan sampel makanan dalam cold box, membawa sampel makanan ke laboratorium, menganalisis kandungan BTP pada sampel makanan dan mencatat kandungan BTP sampel makanan pada formulir identifikasi BTP. Analisis BTP pangan street food dilakukan dengan alat food contaminat detection kit.
Data faktor individu pedagang (Umur, pendidikan, pendapatan) serta asal pangan street food diperoleh dengan melakukan wawancara menggunakan kuesioner terstruktur. Pendidikan adalah pendidikan formal terakhir yang ditempuh oleh pedagang street food, dikategorikan menjadi 1) pendidikan tinggi : Akademi, PT, 2) Pendidikan menengah : SMP, SMA, 3) Pendidikan rendah : Tidak sekolah, SD. Umur pedagang adalah usia biologis pedagang saat penelitian dilaksanakan. Pendapatan adalah hasil dalam bentuk uang yang diperoleh pedagang dari hasil berjualan street food dalam satu hari (Rupiah/hari), serta asal pangan street food adalah dari mana pangan street food yang dijual oleh pedagang berasal dengan kategori 1) Produksi sendiri dan 2) membeli dari pedagang lain. Analisis data dilakukan secara deskriptif dengan menggunakan tabel distrubusi frekuensi, grafik dan penghitungan nilai statistik.

\section{HASIL DAN PEMBAHASAN}

Penelitian ini dilaksanakan di jalan Siliwangi depan kampus 
Universitas Siliwangi. Pengambilan sampel dilakukan pada siang hari pukul 10 sampai 12 WIB selama 2 hari pada tanggal 13 dan 14 juli 2016. Pengambilan sampel dilakukan terhadap 37 Street food dari 18 orang pedagang yang sekaligus menjadi responden dalam penelitian ini. Alasan pengabilan sampel pada siang hari karena memang terdapat perbedaan jenis street food yang dijual pada siang dan malam hari. Pada siang hari jumlah pedagang street food lebih banyak dan jenis street food yang dijual juga lebih beragam.

\section{Karakteristik Responden}

Karakteristik responden yang diukur dalam penelitian ini meliputi pendidikan, umur dan pendapatan responden

\section{Tabel 1 Distribusi Frekuensi Karakteristik Responden}

\begin{tabular}{lcc}
\hline \multicolumn{1}{c}{ Variabel } & n & \% \\
\hline Jenis Pendidikan & & \\
SD & 7 & 38,9 \\
SMP & 6 & 33,3 \\
SMA & 5 & 27,8 \\
\hline Kategori Pendidikan & & \\
Rendah & 7 & 38,9 \\
Menengah & 11 & 61,1 \\
Tinggi & 0 & 0 \\
\hline
\end{tabular}

Hasil penelitian menunjukkan bahwa dari 18 responden, jumlah responden yang berpendidikan SD $(38,9 \%)$ dan SMP $(33,3 \%)$ hampir berimbang. Analisis lebih lanjut menunjukan bahwa lebih dari setengah responden masuk kategori pendidikan menengah (SMP dan SMA), dan tidak ada responden yang berpendidikan tinggi (Akademi dan PT). Hasil penelitian ini juga menunjukkan bahwa masih ada responden yang berpendidikan rendah (SD) sebanyak 7 orang $(38,9 \%)$. Pendidikan memungkinkan seseorang untuk mengakses informasi dari berbagai macam sumber sehingga diduga dapat memiliki pengetahuan tentang berbagai hal yang lebih baik. Masih adanya responden yang berpendidikan rendah diprediksi dapat berkontribusi pada masih rendahnya pengetahuan mereka terkait dengan penggunaan BTP yang dilarang. 
Tabel 2 Penghitungan nilai statistik

\begin{tabular}{lllll}
\hline Variabel & Mean & SD & Minimal & Maksimal \\
\hline Umur (Tahun) & 35,5 & 11,9 & 15 & 65 \\
\hline Pendapatan (Rp/ & $\mathrm{Rp}$ & $\mathrm{Rp}$ & $\mathrm{Rp}$ & $\mathrm{Rp}$ \\
hari) & $314.000,00$ & $202.778,00$ & $100.000,00$ & $700.000,00$ \\
\hline
\end{tabular}

Rata-rata umur 18 pedagang yang menjadi responden dalam penelitian ini adalah 35 tahun, dengan rentang umur berkisar antara 15 tahun sampai dengan 65 tahun. Rata-rata pedagang berumur 35 tahun, ini menunjukkan bahwa rata-rata umur pedagang masuk kategori masih muda. Hasil penghitungan nilai statistik pendapatan responden berada direntang kisaran antara $\mathrm{Rp}$ 100.00,00 perhari sampai $\mathrm{Rp}$ 700.000,00 per hari. Rata-rata pendapatan dari hasil penjualan makanan jajanan street food dalam satu hari adalah $\operatorname{Rp} 314.000,00$. Rata-rata pendapatan pedagang lebih tinggi dari UMR yang ditetapkan di Kota Tasikmalaya, yaitu $\mathrm{Rp}$ 1.600.000,00 per bulan. Tingginya pendapatan memungkinkan pedagang mampu membeli alat-alat yang dapat dijadikan sebagai sumber untuk mengakses informasi termasuk informasi tentang BTP seperti gadgets (gawai), majalah atau koran.

Deskripsi Street Food yang dijual di Jalan Siliwangi Depan Kampus Universitas Siliwangi

Makanan jajanan yang dijual di pinggir jalan atau street food yang dijadikan sampel dalam penelitian ini adalah makanan jajanan yang sudah siap untuk dikonsumsi tanpa memerlukan pengolahan lebih lanjut. Jenis makanan jajanan street food yang diambil sebagai sampel dan diperiksa sebagian besar adalah tahu dengan berbagai jenisnya seperti tahu baso, tahu isi (Gehu dalam bahasa sunda), tahu goreng, dan tahu aci. Kemudian yang menempati urutan kedua paling banyak adalah gorengan dengan jenis seperti bala-bala, cipe, pisang goreng dan cireng. 


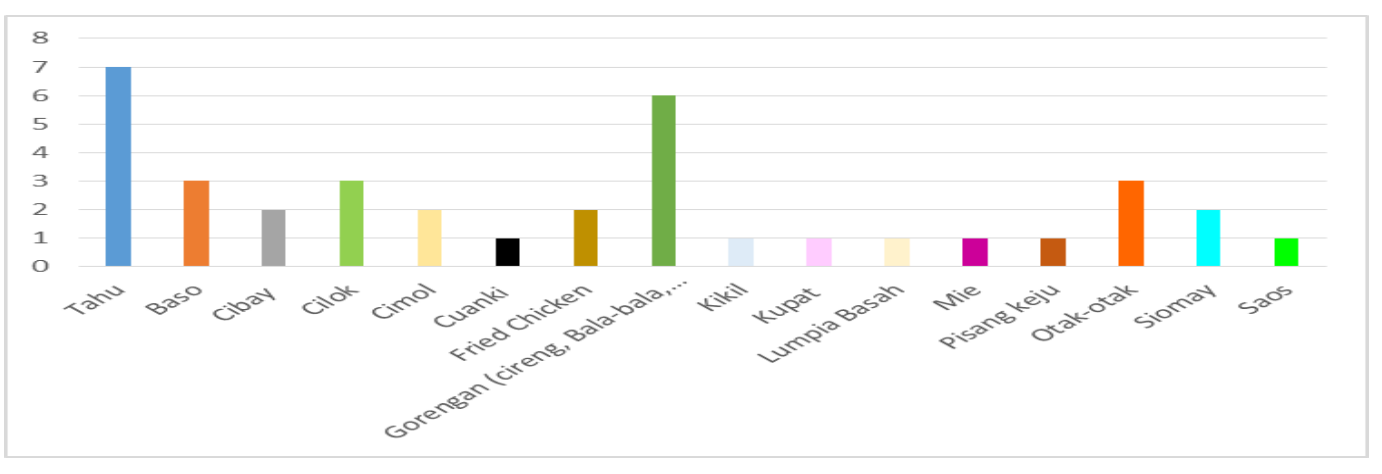

Grafik 1. Jenis Street Food yang dijual responden

Street foods biasanya perkotaan khususnya gaya hidup merupakan makanan dan minuman terkait konsumsi makan pada yang bisa langsung dikonsumsi (siap kelompok masyarakat dengan saji). Makanan ini disiapkan oleh penghasilan menenah dan bawah. pedagang dan/atau dijual oleh Harga Street foods lebih murah dan pedagang di pinggir jaan atau mudah diperoleh serta dapat tempat-tempat lain yang sejenis. dijadikan sebagai makanan utama Menjamurnya street food merupakan (FAO, 2007).

bagian dari gaya hidup masyarakat di

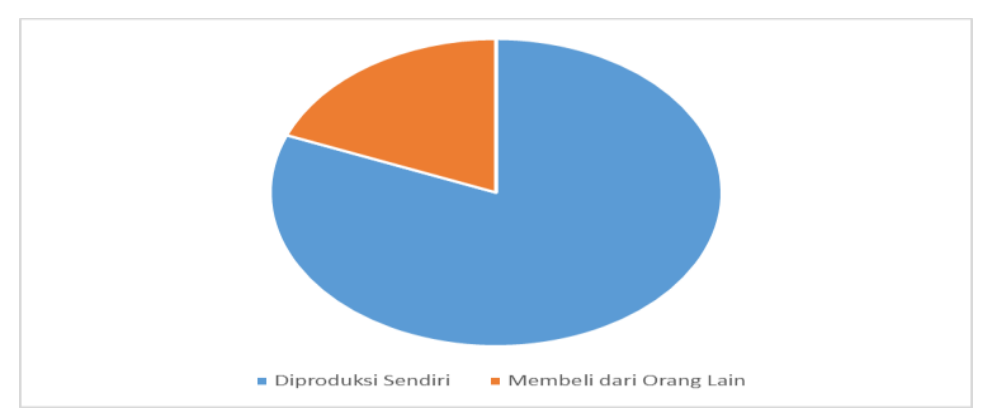

Grafik 2. Asal Street Food yang dijual responden

Hasil wawancara dengan pedagang street food menunjukkan bahwa sebagian besar makanan jajanan yang mereka dijual di pinggir jalan (Street Food) merupakan makanan jajanan yang diproduksi sendiri oleh pedagang $(81,1 \%)$. Oleh karena, Pedagang memproduksi sendiri makanan jajanan yang mereka jual, maka pengetahuan 
tentang higiene sanitasi makanan jajanan sangat menentukan kualitas higiene sanitasi makanan yang mereka jual. Di samping itu, makanan jajanan yang diproduksi sendiri juga menghindari pemeriksaan BTP untuk dua makanan jajanan dengan asal makanan yang sama.

Pedagang street food biasanya tidak hanya menjual satu jenis makanan saja, namun terkadang mereka menjual beberapa makanan jajanan sekaligus dalam satu gerobak makanan. Seperti pedagang gorengan, selainnya menjual tahu isi mereka juga menjual cireng, balabala, dsb. Disamping itu, terkadang untuk satu jenis makanan jajanan terdiri dari beberapa jenis makanan dan masing-masing makanan dapat mengandung potensial BTP yang berbeda. Seperti soto mie yang terdiri dari mie, kikil dan saos dengan potensi kandungan BTP untuk masing-masing makanan yang berbeda. Oleh karena itu, terkadang pada satu pedagang street food jumlah sampe makanan jajanan yang diambil dapat berjumlah lebih dari satu buah.

Tabel 3 Jumlah makanan jajanan yang dijual

\begin{tabular}{ccc}
\hline $\begin{array}{c}\text { Jumlah jenis street } \\
\text { food yang dijual } \\
\text { (Buah) }\end{array}$ & $\begin{array}{c}\text { Jumlah pedagang yang } \\
\text { menjual (Orang) }\end{array}$ & Kumulaif \\
\hline 1 & 11 & 11 \\
2 & 2 & 4 \\
3 & 1 & 3 \\
4 & 1 & 4 \\
5 & 3 & 15 \\
\hline Total & 18 & 37 \\
\hline
\end{tabular}

Pada penelitian ini, sampel street food sebanyak 37 buah yang diperoleh dari 18 pedagang. Tabel 3 menunjukkkan bahwa ada 11 pedagang yang menjual 1 jenis makanan jajanan. Jumlah ini merupakan yang paling banyak dibandingkan dengan yang lainnya.

\section{Deskripsi hasil pemeriksaan}

Pada penelitian ini, pemeriksaan BTP yang dilakukan adalah pemeriksaan keberadaan formalin, 
boraks dan Rhodamin B. Untuk masing-masing pemeriksaan dilakukan pada kelompok makanan yang dicurigai biasa diberi tambahan BTP tertentu. Seperti ketupat, merupakan makanan jajanan yang biasanya ditambah dengan boraks untuk memberikan tekstur kenyal, saos biasanya diberi tambahan Rhodamin B untuk memberikan warna merah yang terang dan menarik, serta formalin yang biasanya ditambahkan pada tahu atau mie untuk menjaga keawetan makanan jajanan.

Tabel 4. Deskripsi hasil pemeriksaan kandungan BTP pada street food

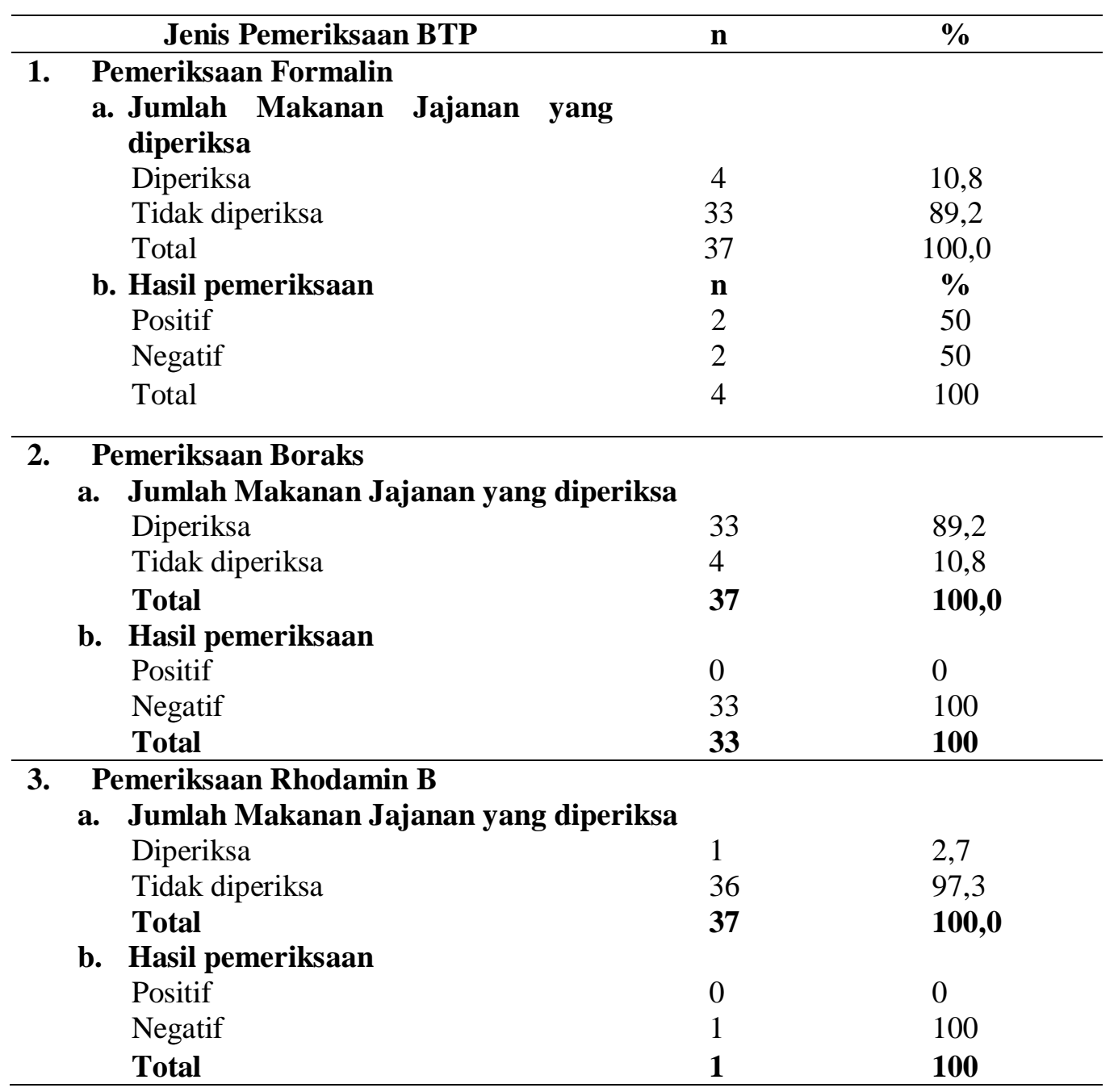


Pemeriksaan formalin dilakukan pada makanan-makanan jajanan yang dicurigai mengandung formalin saja seperti mie, kikil, dan tahu. Pada penelitian ini pemeriksaan formulin dilakukan pada sampel makanan jajanan sebanyak 4 buah $(10,8 \%)$, dan ada 33 buah $(89,2 \%)$ jenis makanan jajanan yang tidak diperiksa kandungan formalinnya karena bukan merupakan makanan yang dapat dicurigai mengandung formalin. Dari hasil pemeriksaan terhadap 4 jenis makanan jajanan yang dicurigai mengandung formalin $2(50 \%)$ jenis makanan dinyatakan positif mengandung formalin. Pemeriksaan boraks dilakukan terhadap 33 jenis makanan jajanan street food dengan hasil semuanya (100\%) tidak mengandung boraks. Hasil yang sama juga diperoleh pada pemeriksaan Rhodamin B. Satu sampel street food yang diperiksa diperoleh hasil yang negatif artinya makanan tersebut tidak mengandung Rodhamin B.

Pada kenyataannya masih ada pedagang street food yang secara sengaja menggunakan formalin. Berdasarkan pemeriksaan dengan menggunakan food contaminat detection kit kandungan formulin ditemukan pada dua jenis street food yaitu mie dan kikil Formalin merupakan BTP yang dilarang penggunaannya karena berbahaya bagi kesehatan. Efek dari bahan tambahan pangan yang dilarang tidak dapat langsung dirasakan, tetapi secara perlahan dan pasti dapat menyebabkan sakit. Penyimpangan atau pelanggaran mengenai penggunaan BTP yang sering dilakukan oleh produsen pangan, yaitu : 1) menggunakan bahan tambahan yang dilarang penggunaannya untuk makanan; 2) menggunakan BTP melebihi dosis yang diizinkan.

Badan pengawasan obat dan makanan (BPOM) mengungkapkan bahwa berbagai BTP yang sering digunakan pada makanan adalah formalin, rhodamin, methanil yellow dan boraks. Semua BTP yang disebutkan tersebut dilarang penggunaannya untuk makanan dan dapat menimbulkan bahaya bagi kesehatan. Penggunaan bahan tambahan yang beracun atau BTP yang melebihi batas akan membahayakan kesehatan masyarakat, dan berbahaya bagi 
pertumbuhan generasi yang akan datang.

Cemaran kimia adalah adanya kontaminasi bahan kimia pada makanan, baik disengaja maupun tidak di sengaja. Bahan kimia yang sengaja ditambahkan dalam makanan untuk kepentingan meningkatkan kualitas makanan dikenal dengan istilah Bahan Tambahan Pangan (BTP). Sementara kontaminasi bahan kimia yang tidak disengaja contohnya adalah tercemarnya pangan karena limbah pabrik, penggunaan pestisida, dll (Mahmud Yunus, 2015).

Penggunaan BTP pada pangan tidak memberikan dampak jangka pendek yang dapat dirasakan, kecuali pada dosis yag sangat besar. Namun efek penggunaan BTP bersifat kumulatif yang akan disimpan sedikit demi sedikit di dalam tubuh. Damapak jangka panjang penggunaan BTP dapat menimbulkan kanker (Tubagus, dkk, 2013).

\section{Simpulan dan saran}

Simpulan

Hasil penelitian ini menunjukkan bahwa semua street food yang diperiksa kandungan boraks dan rhodaminnya, dinyatakan negatif atau tidak mengandung boraks dan rhodamin. Sedangkan dari 4 jenis street food yang diperiksa kandungan formalinnya, didapatkan hasil 2 jenis makanan yaitu mie basah dan kikil positif mengandung formalin.

Saran

Masih ditemukannya formalin pada mie basah dan kikil pada street food menunjukkan bahwa masih diperlukan upaya pemantauan dan edukasi secara berkala dan kontiyu kepada pedagang street food mengenai bahaya penambahan BTP yang dilarang pada kesehatan.

\section{DAFTAR PUSTAKA}

FAO. 2007. Ensuring Quality and Safety of Street Foods. FAO

Tubagus, Gayatri citraningtyas, Fatimawali. 2013. Identifikasi dan penetapan kadar boraks dalam bakso jajanan di kota manado. Pharmacon vol.2 no.04 november 2013 issn 23022493. Jurnal ilmiah farmasi-unsrat

Mahmud Yunus, 2015. Higiene Sanitasi Pangan, Direktorat Penyehatan Lingkungan, Ditjen Pp \& Pl Kementerian Kesehatan Ri Disampaikan Pada Workshop Peringatan Hari Gizi Nasional (Hgn) Ke 55 Tanggal 24 Februari 2015 Di Balai Kartini Jakarta Selatan 
Susana., Indrawani., Yvonne M., Margonda Depok, Jawa Zakianis, 2010. barat. Volume 5, nomor 3, Kontaminasi Bakteri Escherechia Coli Pada Makanan Pedagang Kali Lima Di Sepanjang Jalan desember 2010: 110-115: Jurnal Kesehatan Masyarakat Nasional 